\title{
Attitudes toward Product Placement: A Cross-Cultural Analysis in Tunisia, France, Italy, and Poland
}

\author{
Slim Khalbous ${ }^{1}$, Donata Vianelli ${ }^{2}$, Tomasz Domanski ${ }^{3}$, Christian Dianoux $^{4} \&$ Meriem Maazoul $^{5}$ \\ ${ }^{1}$ University of Carthage, Tunisia \\ ${ }^{2}$ University of Trieste, Italy \\ ${ }^{3}$ University of Lodz, Poland \\ ${ }^{4}$ University of Paul Verlaine-Metz, France \\ ${ }^{5}$ University of Tunis, Tunisia \\ Correspondence: Slim Khalbous, University of Carthage, Tunis, Tunisia. E-mail: Slim.khalbous@gnet.tn
}

Received: January 20, 2013 Accepted: February 16, 2013 Online Published: March 5, 2013

doi:10.5539/ijms.v5n2p138 URL: http://dx.doi.org/10.5539/ijms.v5n2p138

\begin{abstract}
The internationalization of the film industry has contributed greatly to the development of intercultural placements of products and brands as audiovisual supports. Therefore, it becomes interesting to study the efficiency of this communication technique for different cultures. This cross-cultural research address a substantial gap of the literature investigating the effects of placement from a demand-side perspective in four different countries - two Western European, one Eastern European, and a South Mediterranean. The results reveal the significant disparities among cultures with regard to appreciation for advertising, placement in general, and creative placement techniques in particular.
\end{abstract}

Keywords: international advertising, product placement, cultural differences, attitudes

\section{Introduction}

The increasing internationalization of movie industries, close co-operation between movie and television channels in the production of audio-visual material, and growing international diffusion of television channels through satellites all have contributed to the internationalization of placement techniques (Delorme, Mennicken, \& Haleff, 2000 ; Turner, 2004). For the European Union product placement means "any form of audiovisual commercial communication consisting of the inclusion or reference to a product, a service or the trade mark thereof so that it is featured within a program, in return for payment or for similar consideration" (EU, 2007, L.332/35). With the saturation of traditional media, this communication practice increasingly is used by companies with international brands (Lehu \& Bressoud, 2008; Banerjee, 2009). These firms insert mentions of their products and brands in various entertainment products, including movies, television programs, video games, video clips, or even books.

Existent literature pertaining to product placement focuses on three related areas. First, some studies try to build theoretical frameworks and classify placement techniques according to communication modes (Russell, 1998; Fontaine, 2000, 2006; Dalli, 2005; Khalbous \& Maazoul, 2005; Balasubramanian, Karrh \& Patwardhan, 2006). Second, other analyses consider the contents of the audio or visual productions (Englis, Solomon \& Olofsson, 1993; Rubbo \& Berneman, 2004; Smit, Reijmersdal, \& Neijens, 2009). Third, researchers appear interested in placement effectiveness, in terms of attitudes, recognition and memorization (Babin \& Carder, 1996; Gupta \& Gould, 1997; Gupta \& Lord, 1998; D'Astous \& Séguin, 1999; Russell, 2002; Karrh, McKee \& Pardun, 2003; Yang \& Roskos-Ewoldsen, 2007). The latter two streams produce more intercultural analyses (Gould, Gupta, \& Grabner-Kräuter, 2000; Karrh, Frith \& Calisson, 2001; McKechnie \& Zhou, 2003). But from one country to another, the use of academic study to better understand the efficiency of placement is quite variable (Graig-Lee, Scott \& Wong, 2008)

Even though, product placement as a promotional medium is relatively recent. It has gained importance in the marketing communications of international advertisers, largely, because it offers systematic duplication through the internationalization of the movie industry, especially new global media and international stars. It therefore 
becomes legitimate to wonder a strategic question in term of market segmentation: is placement really an effective international communication mode? To determine some answers to this question, this study undertakes intercultural research on attitudes toward placement in four countries.

\section{Intercultural Dimensions of Product Placement}

The originality of product and brand placement as a communication technique has encouraged several researchers to study its use, as well as its perception and acceptance by audiences from different cultures.

\subsection{Communication, Attitudes and Cultural Differences}

Product placement is a unique marketing communication technique, in that product presence is evident but only in a non-commercial context. Consequently, placement effectiveness likely reflects theories of advertising persuasion and consumer information processing (Nebenzahl \& Secunda, 1993; Falcy, 1997; Russell, 1998; D'Astous \& Séguin, 1999; Fontaine, 2000). A study of attitudes toward placement therefore can be situated within a more general framework of attitudes toward advertising (Gupta, Balasubramanian, \& Klassen, 2000; Tiwsakul, Hackley \& Szmigin, 2005).

When a consumer is conscious of the product's or brand's placement in a non-commercial context, that person inevitably compares it to more traditional advertising tools. In the viewer's mind, this logical connection should be much stronger than that derived from an advertising campaign placement used with other techniques. According to this logic, the placement technique essentially should reflect a policy of communication reinforcement (Brée, 1996; D’Astous \& Séguin, 1999).

Attitudes toward advertisements tend to be either favourable or unfavourable (Batra \& Ray, 1986; Holbrook \& Batra, 1987; MacKenzie \& Lutz, 1989). Research into advertising persuasion shows that attitude toward the Ad has a strong influence on advertising effectiveness. Liking or disliking an advertisement can be a good indicator of its effectiveness (Gardner, 1985; Walker \& Dubitsky, 1994; Biel, 1990).

Studies that measure differences in international consumers' attitudes and hierarchical effects show that diverging attitudes exist toward advertisements across various countries and cultures. For example, Gould et al. (2000) found that Americans positively accept product placement and are more likely to report purchase intentions toward placed brands, whereas in Austria and France consumers are less favourable. This result was confirmed by McKechnie and Zhou (2003) who showed that Americans consider placement as more acceptable than do Chinese consumers.

In another study comparing the United States and Russia (Andrews, Durvasula \& Netemeyer, 1994), the Russian consumers have a better attitude toward advertisements than U.S. consumers, who sense negative social effects of it. Russians instead regard advertisements as an essential phenomenon, undoubtedly thanks to the important socio-economic and socio-cultural changes that have occurred since perestroika. Yet the study also shows that U.S. consumers favourably consider advertising an institution, which probably reflects the long-standing experience U.S. consumers have with marketing communications.

Cultural differences also exist between Eastern and Western European countries (Heyder, Musiol \& Peters, 1992). English consumers present a more favourable attitude toward advertisements than do French and German consumers (all Western) and Czechoslovakia (Czech Republic and Slovakia now) provides among the most favourable ratings, whereas Poland, Hungary, and (East) Germany are the least favourable. These results were confirmed more recently by other researches which found that the marketing environment in Central Europe is still considerably different from the one in Western Europe (Gulyas, 2003) and cross national differences in consumer response to advertising can be found also within Central Europe (Orth, Koenig \& Firbasova, 2007; Petrovici \& Marinov, 2007). This indicates the need for advertising adaptations from one country to the other.

These studies, in combination, also seem to imply that the significant attitudes differences among countries may relate to whether the communication techniques are relatively more or less developed in those countries (Marinov, Marinova, Manrai \& Manrai, 2001; Usunier \& Lee, 2005).

\subsection{Normative Acceptance of Product Placement According to Culture}

Early research often defines product placement as a form of persuasive communication in which the intention to persuade is not always highlighted. However, the increasingly ostentatious use of placements in recent years is decreasing the force of this distinctive postulate (Karrh et al., 2003). When an audience realizes the objective of a product placement, it may start feeling manipulated by the communication media. For example, the presence of the mineral water brand Perrier in the James Bond movie Goldeneye - in which it appeared as thousands of bottles in a truck, shown in a long, close-up shot was judged as too aggressive in some countries (Brée, 1996). 
Advertisers need to preview the effect of their product placement, especially if the audience may be perfectly conscious of the persuasive effect sought by that advertiser. In particular, they need to consider the degree of acceptance of product placement advertising in different cultures. Consumer acceptance or refusal of the practice of placing brands in audio-visual entertainment varies significantly according to the country. Existing literature distinguishes three levels of normative acceptance: total acceptance, total refusal and an intermediate position known as conditioned utilization.

Thus, some researchers emphasize the freedom of product placements, especially when a given culture does not require placement regulations. Placement techniques should not disturb the consumer and can make movies more realistic (Nebenzahl \& Secunda, 1993; Gupta et al., 2000; Tiwsakul, Hackley \& Szmigin, 2005). However, other researchers recognize that certain consumers consider placement as a dangerous technique, because its implicit and subliminal influence causes them to become suspicious (Galician, 2004). Moreover, some consumer advocacy groups have demanded government regulations on placement practices to avoid any potential abuses (Rothenberg, 1991; Gupta et al., 2000; Morton \& Friedman, 2002).

Thus, placement regulations undoubtedly will be the subject of researches in coming years. For example, ethically questionable products such as alcohol, cigarettes and weapons are rejected in many countries (Gupta \& Gould, 1997; McKechnie \& Zhou, 2003, Tiwsakul et al, 2005). Indeed, Korean people support government regulation toward placement, which is not the case of Americans (Lee, Sung \& De Gregorio, 2011).

Other possible limits relate to children's movies, which target a vulnerable audience (EU, 2007, L 332/41). Some observers argue that placements negatively influence teenagers, which affects a large target market for movies (Poncin, 2007). Regulation might limit the use of placement techniques according to the types of products. These differences in acceptance levels require additional data, especially in the context of an intercultural study.

\subsection{Effectiveness of Product Placement across Cultures}

If placement techniques are generally accepted, the next fundamental question becomes whether attitudes toward placement differ from one culture to another. The research that has become the primary reference in this field is made by Gupta and Gould (1997). It suggests some factors that appear likely to influence the acceptance of placement techniques by Americans. Generally, U.S. consumers tolerate this technique, except for certain types of products, though they note some differences based on gender. For example, non-ethical product placement is better accepted by U.S. men than by women.

Several researchers adapt this study to intercultural applications and show that attitudes toward placement vary within cultures. For example, Gould et al. (2000) consider product placement effectiveness in the United States, France and Austria using a comparison based on three criteria: country, product nature, and respondents' individual characteristics. They find that U.S. consumers accept product placement tools better than do the Austrians or French. Moreover, their U.S. respondents indicate higher purchase intention scores than the French and Austrian respondents. Regarding the impact of individual differences and kinds of products, the results show no differences in the nature of the answer but a difference in the degree of acceptance. For three countries, movies buffs and men accept the placement of non-ethical products more easily, with some differences in the acceptance levels between the countries.

In the same spirit, the study of Guido et al. (2010) compare appreciation of product placement between Italy, USA, France, Austria, China and Australia on certain categories of product. It appears that Italians are the least those who appreciate the placement examined for the same product categories. Indeed, Americans and French are those who are most likely to accept the placement technique.

The study of Karrh et al. (2001) compares attitudes toward product placement between the United States and Singapore. Not only are Singaporeans less likely to accept non-ethical products, but they also appear less aware of product placement as a form of paid advertisement whose aim is to influence the viewer. When they become aware of this technique, they become very suspicious. The result is similar in China (McKechnie \& Zhou, 2003). Individualistic Americans tend to favour placement more than collectivist Chinese, though both cultures express dislike for the placement of non-ethical products. However, gender does not emerge as a discriminating variable for the Chinese sample.

A study made by de Lee et al. (2011) shows that Americans are more likely to agree that product placement enhance the realism of media content than Koreans. According to the findings, Americans tend to accept the placement technique in most films genres, while according to Korean viewers' drama is the most appropriate genre.

According to the study made by Tiwsakul and Hackley (2005), conducted in British context, the British seem less 
favourable toward the placement than the Americans. Their research also shows that placements of alcoholic products are accepted in the same manner by both men and women.

In summary, previous studies generally imply a positive attitude toward placement. Audiences may feel overloaded by traditional advertisements and thus prefer original techniques, such as product placement. However, product placement effectiveness varies across different cultures, even though most intercultural research applies a comparison with U.S. consumers' attitudes, rarely addressing emerging or developing countries.

\subsection{Effectiveness of Product Placement Creative Techniques}

What are product placement creative techniques? As a communication technique, product placement is characterized by its creative dimensions. Furthermore, the placement that product or brand gains in an entertainment piece constitutes a key component of consumer persuasion. For example, a movie producer must be able to incorporate the product into a film and possibly assign a role to the brand or product to succeed in attracting the target.

According to previous literature, placement effectiveness largely depends on the audience's attitudes toward the creative dimensions, which consist of three categories: audio-visual context, integration and prominence (D'Astous \& Séguin, 1999; Russell, 2002; Fontaine, 2006; Khalbous \& Maazoul, 2005).

The audio-visual context has two dimensions: verbal. This is defined as a spoken citation of the brand's name in dialog and visual, which refers to the product's appearance on screen. Marketing communication research demonstrates that the simultaneous presence of both visual and verbal dimensions makes the placement more effective (Russell, 2002).

The level of integration depends on the degree of the product's contribution to the content and the importance of its role in the program (D'Astous \& Séguin, 1999). For strong integration, or 'central placement,' the product and the brand are clearly identified on screen and become an essential part of the movie (e.g., Austin Martin or BMW cars in James Bond movies; Guillaume, 2002). In contrast, weak integration implies 'peripheral placement. Thus, when audio-visual integration is strong, the brand takes a leading role and consumer attention becomes more important, processing of cognitive information is more elaborate and memorization becomes easier (Russell, 1998).

Finally, prominence refers to the product's ability to attract consumer attention and thus depends on several factors, including a product's characteristics, its centrality on the screen and its contribution to the plot (Cowley \& Barron, 2008). A prominent placement likely uses sharp colours, appears large on the screen, and/or relates to a scene with movement, contrast or some new and unexpected elements (Babin \& Carder, 1996; Gupta \& Lord, 1998; D'Astous \& Séguin, 1999). Research on product placement effectiveness appears divided with regard to the prominence effect: some authors suppose that an ostentatious presence draws attention and influences memorization positively, whereas others argue that an obvious placement generates unfavourable attitudes because it reveals the intention to influence the audience (Brée, 1996; Gupta \& Lord, 1998).

Table 1. Definition and effect of creative dimensions

\begin{tabular}{|c|c|c|c|c|}
\hline & & Definition & Authors & Effect \\
\hline \multirow[b]{2}{*}{ audio-visual } & Visual & Product's appearance on screen & \multirow{4}{*}{$\begin{array}{l}\text { Russell (1998) } \\
\text { D'Astous \& } \\
\text { Séguin (1999) } \\
\text { Russell (2002) }\end{array}$} & \multirow{4}{*}{$\begin{array}{l}\text { When audio-visual integration is } \\
\text { strong, brand takes a leading role } \\
\text { and consumer attention becomes } \\
\text { more important, processing of } \\
\text { cognitive information is more } \\
\text { elaborate and memorization } \\
\text { becomes easier }\end{array}$} \\
\hline & Verbal & $\begin{array}{l}\text { Spoken citation of the brand's } \\
\text { name in dialog }\end{array}$ & & \\
\hline \multirow[t]{2}{*}{ Integration } & $\begin{array}{l}\text { Central } \\
\text { placement }\end{array}$ & $\begin{array}{l}\text { Product and brand are clearly } \\
\text { identified on screen and become } \\
\text { an essential part of the movie } \\
\text { (e.g., Austin Martin or BMW cars } \\
\text { in James Bond movies; } \\
\text { Guillaume, 2002) }\end{array}$ & & \\
\hline & $\begin{array}{l}\text { Peripheral } \\
\text { placement }\end{array}$ & $\begin{array}{l}\text { Appearance not justified of the } \\
\text { brand on the movie or the } \\
\text { program relative to the scenario }\end{array}$ & & \\
\hline
\end{tabular}




\begin{tabular}{|c|c|c|c|c|}
\hline \multirow[t]{2}{*}{ Prominence } & $\begin{array}{l}\text { Prominent } \\
\text { placement }\end{array}$ & $\begin{array}{l}\text { Which draws attention? Uses } \\
\text { sharp colours, appears large on } \\
\text { the screen, and/or relates to a } \\
\text { scene with movement, contrast, } \\
\text { or some new and unexpected } \\
\text { elements }\end{array}$ & \multirow{2}{*}{$\begin{array}{l}\text { Babin \& } \\
\text { Carder (1996) } \\
\text { Brée (1996) } \\
\text { Gupta \& Lord } \\
(1998) \\
\text { D'Astous \& } \\
\text { Séguin (1999) } \\
\text { Cowley \& } \\
\text { Barron (2008) }\end{array}$} & \multirow{2}{*}{$\begin{array}{l}\text { Some authors suppose that } \\
\text { prominence draws attention and } \\
\text { influences memorization } \\
\text { positively, whereas others argue } \\
\text { that subtle placement generates } \\
\text { unfavourable attitudes, because } \\
\text { it reveals the intention to } \\
\text { influence the audience }\end{array}$} \\
\hline & $\begin{array}{l}\text { Subtle } \\
\text { placement }\end{array}$ & $\begin{array}{l}\text { Presence of the product in a subtle } \\
\text { manner } \\
\text { (e.g., in a background) }\end{array}$ & & \\
\hline
\end{tabular}

\subsection{International Effect of Creative Techniques}

Despite the importance of product placement, no intercultural research focuses precisely on creative placement aspects from a demand-side point of view. Thus, no studies measure the impact of the three creative dimensions across several cultures at the same time. However, some studies consider creative dimensions from the supply side. For example, Kouli and Saad (2000) conduct a comparative analysis of the use of product placements in the French and U.S. movie industries. Their results show important differences in creative practices. In particular, French movies contain two times as many placements as U.S. movies, as well as more brands (17.2 on average, versus 9.6 brands in U.S. movies) and more frequent brand appearances ( 2.43 versus 2.06 times). The authors suggest French movies may have greater financing needs. Though, they also note that the presence of many brands in French movies may be a creative choice, in that they make the movie more realistic.

Furthermore, brand appearances seem more central to French than to U.S. movies. In the U.S. context, the placement tends to present the brands positively (e.g., reward for the character) and more in connection with the main characters. In French movies, the brands serve instead to identify the characters' social status. Moreover, U.S. movies are more ethnocentric, featuring more U.S. products than do the French movies highlight French products. Finally, U.S. movies often use products that are symbolic of American consumption (D'Astous \& Séguin, 1999; Rubbo \& Berneman, 2004).

On the basis of this analysis of differences in placement techniques, another research question emerges: What are the differences in the possible decoding across various cultures, if the movies with product placements cross international borders? The subsequent sections attempt to provide some answers based on an empirical study of product placement in four countries with different characteristics: Tunisia, France, Italy and Poland.

\section{Cross-Cultural Comparison of the Attitudes toward Product Placement}

This section presents the methodological approach, followed by issues related to variable selection, data collection methods and measurement tools. Finally, the latter sections analyse the data and attempt to interpret the results.

\subsection{Research Design}

The conceptual part of this research, based on the literature review, identifies four types of variables that reflect audience attitudes toward product placements (Figure 1). The research portion attempts to define these attitudes in four culturally different countries to provide a cross-cultural comparison.

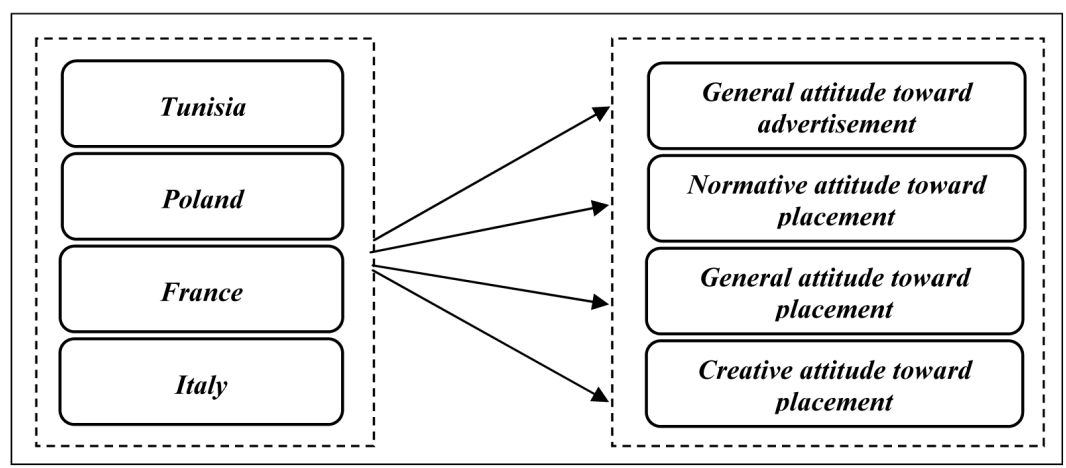

Figure 1. Analysis framework 


\subsubsection{Data Collection and Measurement Models}

This research used a student sample. Young people are great consumers of media such as television and movies, and therefore constitute suitable subjects for the present survey. Indeed, advertisers are very interested in this target, which represents a promising segment in terms of consumption of good and entertainment (McQuail, 2002). Furthermore, this sample is appropriate for cross-cultural comparisons because it consists of the same consumer category (Brée, 1996; Gupta et al., 2000; Poncin \& Pieters, 2002; McKechnie \& Zhou, 2003 Tiwsakul \& Hackley, 2005; Guido et al., 2010; Lee et al., 2011). The final sample contained 763 young people whose average age was between 20 and 23 years. They were selected by non-probability convenience sampling method. These consumers were distributed across the four countries as follows: 260 consumers in Tunisia, 120 in France, 182 in Poland and 201 in Italy.

The measurement of the model's variables was made by an investigation using a self-administrated questionnaire. The investigator gave questionnaires to the respondents while explaining the research aims and sensitizing them to key parts of the questionnaire. The structure of the questionnaire is as follows: firstly, the question on the general attitudes toward advertisement. Secondly, before answering any questions relative to product placement, all participants needed to know what product placement was. Consequently, a definition of product placement was presented on the questionnaire, with an adaptation including appropriate examples for each country sample. Thirdly, the measure of the general attitude toward placement. Then, the question about the normative attitude toward placement. And finally, the respondents have to answer to the question on the attitudes toward creative techniques.

After collecting the questionnaires, the interviewer initiated a discussion on the subject with the subjects, which made it possible to enrich the interpretation elements through exploratory and qualitative information. The pilot test suggested altering some vocabulary but no major changes and the questions were adapted to the characteristics of each culture.

Measurements of three variables of the study are inspired by the study of Gupta \& Gould (1997), which are: general attitudes toward advertisement, normative attitude toward placement and general attitude toward placement.

The measure of general attitudes toward advertisement uses traditional items and a five-point semantic scale, tested previously in the Tunisian context (Gupta \& Gould, 1997; Khalbous, 2003). It comprises a cognitive level, related to the acceptance of advertisements in various media; an emotional level, relating to personal feelings toward advertisements and finally, a behavioural level pertaining to the tendency to pay attention to advertisements.

The normative attitude toward placement uses the measure of McKechnie and Zhou (2003).

The general attitude toward placement measure uses a ten-item scale (Gupta \& Gould, 1997).

The measure of attitudes toward creative techniques uses a previously applied scale (Khalbous \& Maazoul, 2005), on which participants could note the degree of influence of creative elements (audio-visual context, integration and prominence) on nine / five-point scales (Table 1).

Opertionalization details on the four types of variables are presented in the appendix 1 and 2.

\subsubsection{Statistical Analysis}

The data processing began with some association tests (chi-square) and variance analyses (ANOVA) among the four countries and four attitudinal variables, as a means to determine significant differences in the responses. A second phase consisted of a comparison of the means, in an attempt to describe and synthesize the results by country. Finally, a multidimensional analysis of the means in relation to the four countries at the same time (MDS) offers a better interpretation and multidimensional map of the results (Malhotra, Décaudin \& Bouguerra, 2004).

\subsection{Analysis, Results, and Discussion}

\subsubsection{General Attitudes toward Advertisement}

Table 2. General attitudes toward advertisements by country: ANOVA

\begin{tabular}{|c|c|c|c|c|c|}
\hline & $\begin{array}{l}\text { Sum } \\
\text { Squares }\end{array}$ & of $\mathrm{df}$ & $\begin{array}{l}\text { Mean } \\
\text { Square }\end{array}$ & $\mathrm{F}$ & Sig. \\
\hline Cognitive attitude & 225,126 & 3 & 75,042 & 59,285 & 0,000 \\
\hline Affective attitude & 180,847 & 3 & 60,282 & 50,122 & 0,000 \\
\hline Behavioural attitude & 246,890 & 3 & 82,297 & 54,408 & 0,000 \\
\hline
\end{tabular}


As shown in Table 2, the results of the ANOVA show that the relationships between the attitudes toward advertisements in general and the countries are significant for all scale items.

Table 3. General attitudes toward advertisements: comparison among Tunisia, Italy, Poland, and France

\begin{tabular}{llllll}
\hline & $\begin{array}{l}\text { Tunisia } \\
\text { (mean) }\end{array}$ & $\begin{array}{l}\text { Italy } \\
\text { (mean) }\end{array}$ & $\begin{array}{l}\text { Poland } \\
\text { (mean) }\end{array}$ & $\begin{array}{l}\text { France } \\
\text { (mean) }\end{array}$ & Total mean \\
\hline $\begin{array}{l}\text { Accept advertisement } \\
\text { (cognitive attitude) }\end{array}$ & 3.82 & 2.44 & 2.97 & 3.23 & $\mathbf{3 . 1 2}$ \\
$\begin{array}{l}\text { Like advertisement } \\
\text { (affective attitude) }\end{array}$ & 3.62 & 2.41 & 2.81 & 3.24 & $\mathbf{3 . 0 2}$ \\
$\begin{array}{l}\text { Pay attention to advertisement } \\
\text { (behavioural attitude) }\end{array}$ & 3.72 & 2.27 & 2.81 & 3.02 & $\mathbf{2 . 9 6}$ \\
Average by country: & $\mathbf{3 . 7 2}$ & $\mathbf{2 . 3 7}$ & $\mathbf{2 . 8 6}$ & $\mathbf{3 . 1 6}$ & $\mathbf{3 . 0 3}$ \\
\hline
\end{tabular}

To interpret the relationship between variables, the calculation of the means for the various samples indicates the differences in attitudes across the four countries (Table 3).

Generally, attitudes toward advertisements in the Tunisian and, to a lesser extent, French samples are more favourable than those in the Polish and Italian samples. According to the means of the single countries, the scores toward the three attitude components are quite homogeneous. The classification remains the same for the cognitive, affective, and behavioural attitudes. Tunisians reveals the most favourable attitudes, followed by the French and the Polish. Italians appear to be the most hostile toward advertisements. The remainder of this analysis attempts to verify these results by focusing particularly on product placement.

3.2.2 Normative Attitudes toward Product Placement

Table 4. Normative attitudes towards product placement by country: ANOVA

\begin{tabular}{llllll}
\hline & $\begin{array}{l}\text { Tunisia } \\
\text { (mean) }\end{array}$ & $\begin{array}{l}\text { Italy } \\
\text { (mean) }\end{array}$ & $\begin{array}{l}\text { Poland } \\
\text { (mean) }\end{array}$ & $\begin{array}{l}\text { France } \\
\text { (mean) }\end{array}$ & $\begin{array}{l}\text { Total } \\
\text { mean }\end{array}$ \\
\hline Placement status (normative attitude)* & $\begin{array}{l}1.91 \\
\text { Notes: } 1=\text { free; } 2=\text { use with caution; } 3\end{array}=$ prohibited & $\underline{1.95}$ & 1.92 & $\underline{1.78}$ & $\mathbf{1 . 8 9}$ \\
\hline
\end{tabular}

The table 4 shows that the chi-square test between the normative attitude toward placement and the four countries shows a significant relation (0.000). The means analysis reveals other differences in audience attitudes as well. The global tendency leans toward freedom of use, provided that it is somewhat regulated (general average of the four countries $=1.89$ ). Nevertheless, some disparities emerge among the attitudes, such that Italians appear more wary than average, which confirms the first result of this research. In contrast, the French are the most permissive, which is not surprising considering the tendency to support freedom of expression in the French culture.

The following stage includes, in detail, the various components of attitudes toward placements in general and tries to identify the cross-cultural differences that result from these attitudes. 


\subsubsection{General Attitudes toward Product Placement}

Table 5. General attitudes toward product placement by country: ANOVA

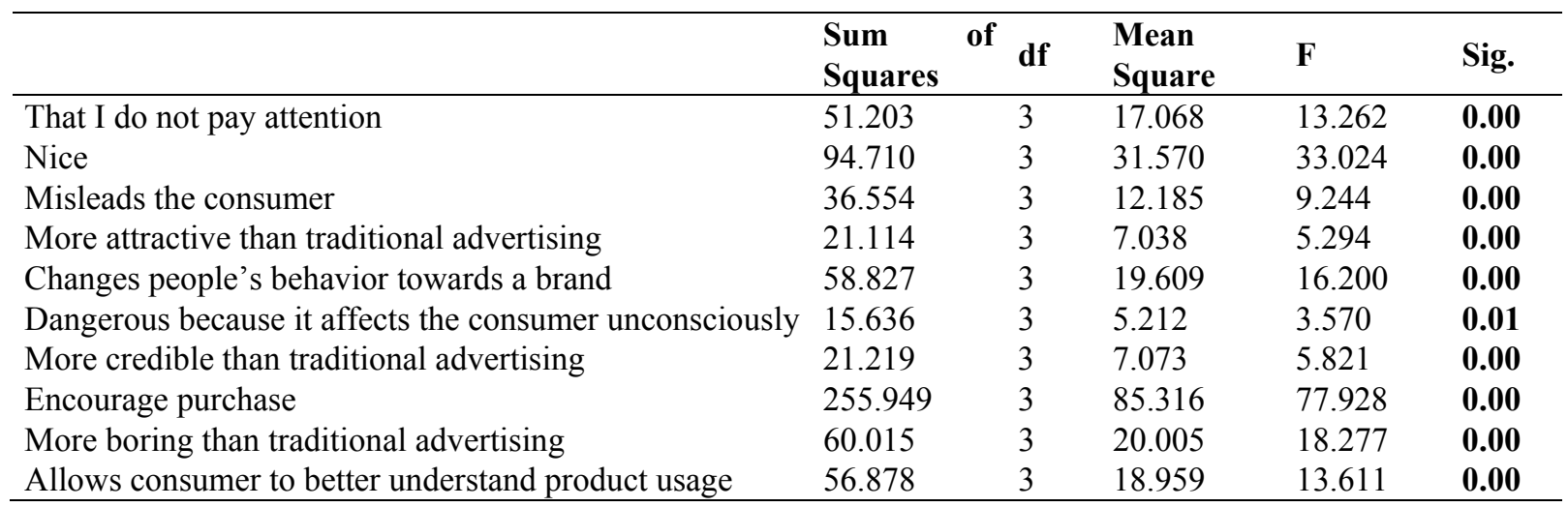

The results of the ANOVA test (Table 5) confirm significant differences among the general attitudes toward placement in the four countries.

A multidimensional analysis based on the means can help to identify countries with relatively homogeneous perceptions of placement.

Table 6. Multidimensional analysis of the attitudes toward placement in the four countries

\begin{tabular}{|c|c|c|c|c|c|c|c|}
\hline & \multicolumn{5}{|c|}{ Attitudes toward Placement } & \multirow[b]{2}{*}{$\begin{array}{l}\text { Axis } 1 \\
(60 \%)\end{array}$} & \multirow[b]{2}{*}{$\begin{array}{l}\text { Axis } 2 \\
(25 \%)\end{array}$} \\
\hline & $\begin{array}{l}\text { Tunisia } \\
\text { (mean) }\end{array}$ & $\begin{array}{l}\text { Italy } \\
\text { (mean) }\end{array}$ & $\begin{array}{l}\text { Poland } \\
\text { (mean) }\end{array}$ & $\begin{array}{l}\text { France } \\
\text { (mean) }\end{array}$ & $\begin{array}{l}\text { Total } \\
\text { mean* }\end{array}$ & & \\
\hline That I do not pay attention & 2.52 & 3.10 & 2.88 & 3.10 & 2.90 & -.198 & 1.172 \\
\hline Nice & 3.03 & 2.43 & 2.80 & 3.49 & 2.94 & .056 & -.087 \\
\hline Misleads the consumer & 2.97 & 2.71 & 2.56 & 3.17 & 2.85 & -.332 & .099 \\
\hline More attractive than traditional advertising & 3.45 & 3.05 & 3.31 & 3.42 & 3.31 & .936 & .004 \\
\hline Changes people's behavior towards a brand & 3.35 & 2.77 & 3.34 & 3.47 & 3.23 & .998 & -.190 \\
\hline $\begin{array}{l}\text { Dangerous because it affects the consumer } \\
\text { unconsciously }\end{array}$ & 2.90 & 2.79 & 3.15 & 3.03 & 2.97 & .097 & .412 \\
\hline More credible than traditional advertising & 3.07 & 2.91 & 2.77 & 3.23 & 3.00 & .111 & .363 \\
\hline Encourage purchase & 3.41 & 2.03 & 3.34 & 3.07 & 2.96 & .291 & -1.085 \\
\hline More boring than traditional advertising & 2.70 & 1.99 & 2.36 & 2.12 & 2.29 & -1.629 & -.356 \\
\hline $\begin{array}{l}\text { Allows consumer to better understand } \\
\text { product usage }\end{array}$ & 3.09 & 2.42 & 2.90 & 2.84 & 2.90 & -.331 & -.332 \\
\hline$* 5=$ total approval; $1=$ total disapproval. & & & & & & $\begin{array}{l}\text { Total } \\
\text { varianc }\end{array}$ & $\begin{array}{l}\text { explained } \\
\mathbf{8 5 \%}\end{array}$ \\
\hline
\end{tabular}

Two axes result from this analysis (Table 6) representing the psychological basis or underlying dimensions used to position the four countries in relation to the characteristics of attitudes toward placement on the same visual level (Figure 2). This interpretation is based on an analysis of the links between the characteristics on the two axes and the countries' relative positions. 


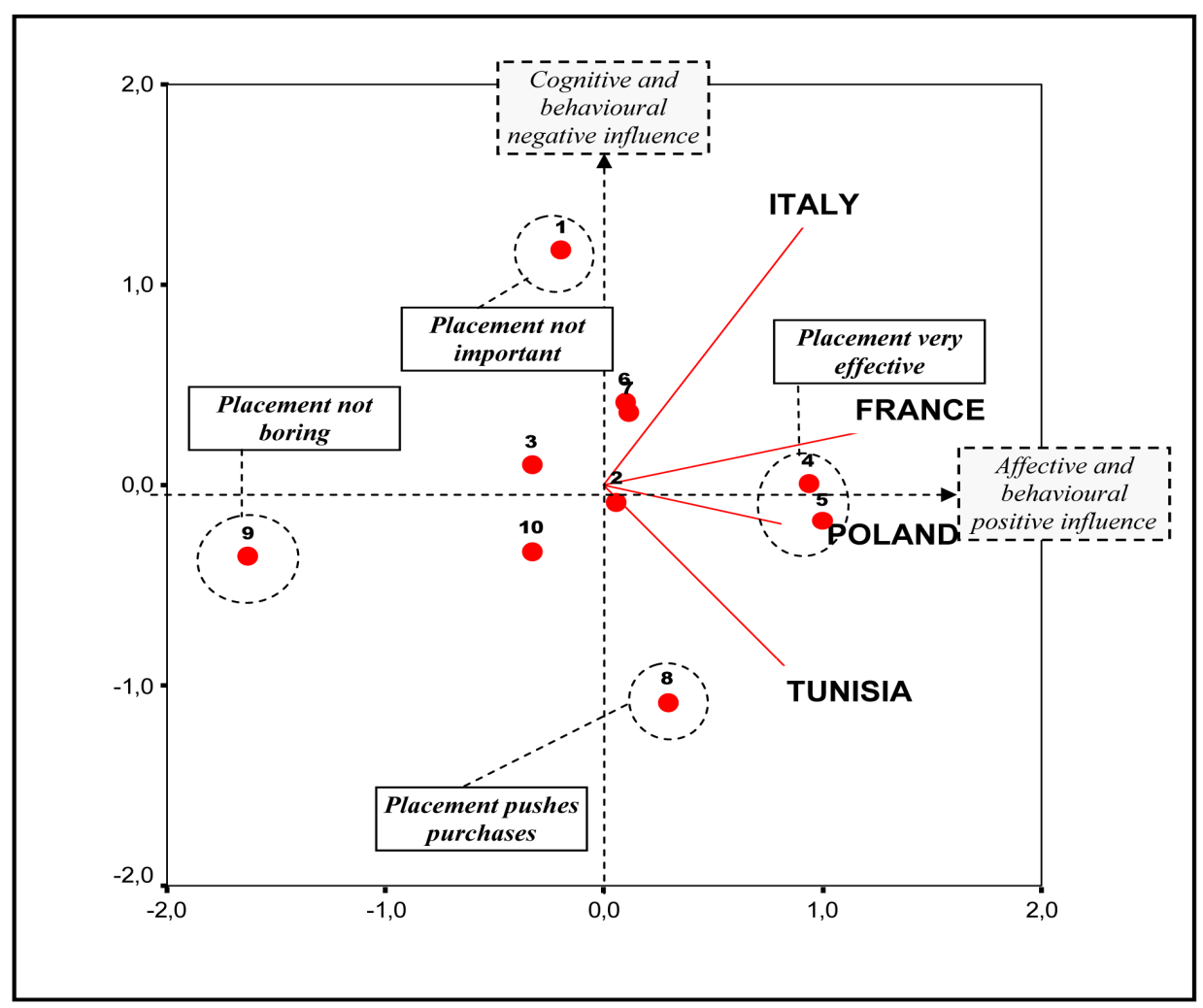

Figure 2. Multidimensional map of attitudes toward placement

The first axis explains $60 \%$ of the explained variance and correlates positively primarily with items 4 and 5 , which represent the affective and behavioural influences. The opposite side of the axis correlates with item 9 and to a lesser extent item 3, two negatives items that do not meet participants' approval. Thus, the first axis may be titled the affective and behavioural positive influence of placement. The second axis, which accounts for only $25 \%$ of the explained variance, correlates primarily with negative attitudes, namely, items 1,6 and 8 . Thus, it takes the title cognitive and behavioural negative influence of placement. The position of the countries according to their attitudes emerges clearly in Figure 2.

Before analyzing the various positions of the countries, the results indicate that overall, though young people are conscious that placement is a commercial technique that pushes them to purchase. They also consider it a more attractive and amusing technique than traditional advertisements.

Two countries that are completely opposite in their attitudes are Italy and Tunisia. The two others take median positions, with some similarities between France and Italy and some between Poland and Tunisia. This result is not surprising, considering the previous findings. Young Italians emerge as the most sceptical of placement effectiveness; without being particularly hostile, they think the technique has little influence on the audience and is not much more enjoyable than traditional advertisements. In contrast, young Tunisians find placement effective, because it draws attention and pushes consumers to purchase.

Similar to the Italians, the French respondents perceive limited product placement influences on consumers; like the Tunisians, they also find it more attractive and enjoyable than traditional advertisement. Finally, the young Polish respondents do not find product placements particularly attractive but think, unlike the Italians and French, that it can prove effective.

The rest of this analysis undertakes a deeper analysis of potential cultural differences by comparing the positions of the four countries in relation to placement implementation techniques in movies. 


\subsubsection{Attitudes toward Placement Creative Techniques}

Table 7. Attitudes toward creative techniques by country: ANOVA

\begin{tabular}{|c|c|c|c|c|c|}
\hline & $\begin{array}{l}\text { Sum } \\
\text { Squares }\end{array}$ & of $\mathrm{df}$ & $\begin{array}{l}\text { Mean } \\
\text { Squares }\end{array}$ & $\mathbf{F}$ & Sig. \\
\hline High frequency of occurrence of the brand & 172.164 & 3 & 57.388 & 39.639 & 0.00 \\
\hline Product associated to the hero & 35.035 & 3 & 11.678 & 8.761 & 0.00 \\
\hline Discreet presence of the brand & 82.356 & 3 & 27.452 & 21.893 & 0.00 \\
\hline Attractive manner with which the actor cites the brand name & 99.977 & 3 & 33.326 & 23.141 & 0.00 \\
\hline Importance of the product & 38.140 & 3 & 12.713 & 8.496 & 0.00 \\
\hline Product in foreground & 50.599 & 3 & 16.866 & 10.942 & 0.00 \\
\hline Product associated to a secondary character & 40.498 & 3 & 13.499 & 12.677 & 0.00 \\
\hline Draw attention to the product & 57.356 & 3 & 19.119 & 16.067 & 0.00 \\
\hline High frequency of verbal citation of the brand name & 195,320 & 3 & 65,107 & 41,185 & $\mathbf{0 , 0 0}$ \\
\hline
\end{tabular}

As shown in Table 7, the ANOVA analysis again reveals significance differences in the studied countries.

Table 8. Multidimensional analysis of attitudes toward creative placement techniques in four countries

\begin{tabular}{|c|c|c|c|c|c|c|c|}
\hline & \multicolumn{5}{|c|}{ Attitudes toward Creative Placement } & \multirow[b]{2}{*}{$\begin{array}{l}\text { Axis } 1 \\
(67 \%)\end{array}$} & \multirow[b]{2}{*}{$\begin{array}{l}\text { Axis } 2 \\
(19 \%)\end{array}$} \\
\hline & $\begin{array}{l}\text { Tunisia } \\
\text { (mean) }\end{array}$ & $\begin{array}{l}\text { Italy } \\
\text { (mean) }\end{array}$ & $\begin{array}{l}\text { Poland } \\
\text { (mean) }\end{array}$ & $\begin{array}{l}\text { France } \\
\text { (mean) }\end{array}$ & $\begin{array}{l}\text { Total } \\
\text { mean* }\end{array}$ & & \\
\hline High frequency of occurrence of the brand & 3.33 & 2.56 & 2.13 & 3.02 & 2.76 & -.799 & .358 \\
\hline Product associated to the hero & 3.70 & 3.21 & 3.41 & 3.72 & 3.51 & 1.106 & .370 \\
\hline Discreet presence of the brand & 3.01 & 3.10 & 3.84 & 3.40 & 3.34 & .361 & -1.060 \\
\hline $\begin{array}{l}\text { Attractive manner with which the actor cites } \\
\text { the brand name }\end{array}$ & 3.65 & 2.72 & 3.26 & 3.08 & 3.18 & -.033 & .259 \\
\hline Importance of the product & 3.47 & 3.22 & 2.88 & 3.17 & 3.19 & 299 & .005 \\
\hline Product in foreground & 3.38 & 2.77 & 2.89 & 2.89 & 2.98 & -.287 & .129 \\
\hline Product associated to a secondary character & 2.93 & 2.43 & 2.88 & 3.06 & 2.83 & -.751 & -.862 \\
\hline Draw attention to the product & 3.88 & 3.17 & 3.56 & 3.49 & 3.53 & 1.093 & .216 \\
\hline $\begin{array}{l}\text { High frequency of verbal citation of the brand } \\
\text { name }\end{array}$ & 3.43 & 2.28 & 2.33 & 2.70 & 2.69 & -.989 & .586 \\
\hline$* 5=$ very positive influence; $1=$ very nega & inf & & & & & $\begin{array}{l}\text { Total } \\
\text { varianc }\end{array}$ & $\begin{array}{l}\text { explained } \\
\text { e: } \mathbf{8 6 \%}\end{array}$ \\
\hline
\end{tabular}

To uncover the nature of the attitudes toward the creative techniques, the same analysis process applies calculating the means for the various samples, followed by a multidimensional analysis, was presented in table 8. Again, two axes emerge that represent underling dimensions; thus, it is possible to position the four countries according to their attitudes toward creative placement techniques (Table 8 and Figure 3). 


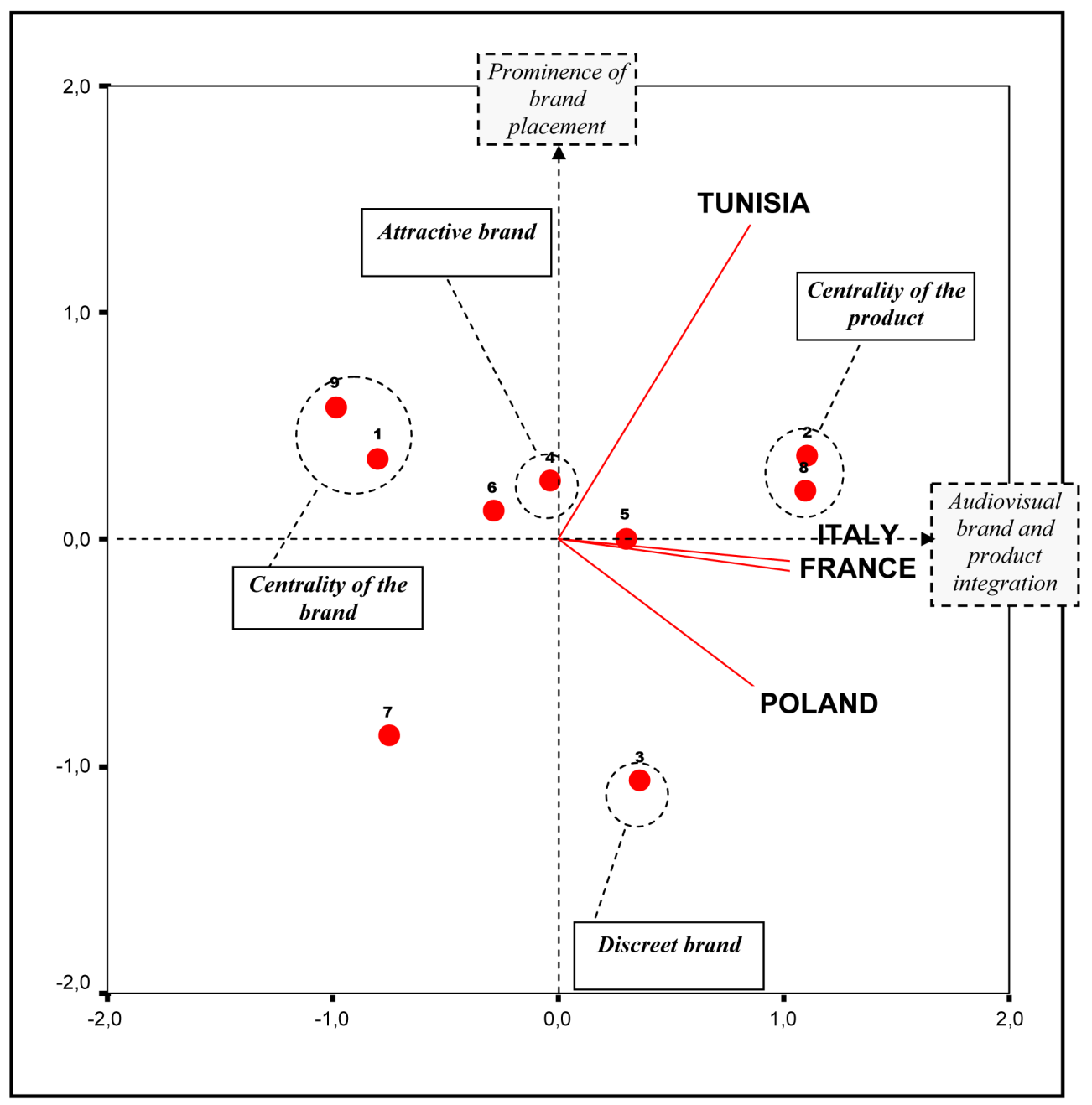

Figure 3. Multidimensional map of attitudes toward creative placement techniques

The first axis, which explains $67 \%$ of the variance, correlates positively with items 2 and 8 , which refer to product development. The negative side of this axis correlates with items 1 and 9, or visual and verbal brand development. This axis therefore represents audio-visual brand and product integration. The second axis accounts for only $19 \%$ of the explained variance. It is primarily correlated, on the negative side, with item 3 and on the other side with item 4 . These two items refer to the brand's capacity to draw attention, so this axis is entitled the prominence of the brand placement.

The results indicate that globally, without analyzing differences in the countries' positions, young people think that regardless of the audio-visual context and for both images and text, placement integration is more influential than prominence. Moreover, in relation to integration techniques, these young respondents believe that the quality of the association of the product with a movie is more effective than a simple, ostentatious presence with higher frequency or more related quotations.

Unlike the general attitudes toward placement, the positions in relation to creative placement techniques are more complex, because they reflect stronger disparities among the studied countries.

First, Tunisia clearly opposes the other three countries with regard to the prominence dimension. Young Tunisians are the only ones who believe that the subtle presence of brands is not influential and that its role needs to be more attractive and visible. This contrast is stronger with the Polish, who favour discretion. The French are more balanced in their attitudes, preferring an attractive brand that does not go too far. Finally, the Italians consistently score lowest though their answer structure is similar to that of the French.

Second, compared with product centrality, the overall scores are higher, but two groups of countries still emerge. The image actually appears a little misleading, because on the one hand, Tunisia and France consider product 
integration very effective, whereas on the other hand, Italy and Poland consider this effectiveness very limited.

Third, the final category of differences arises in relation to brand centrality according to high frequencies. Young Tunisians, who always favour explicit placements, consider this technique very effective. Italians and Polish believe high frequencies are not at all effective. The French sample takes a middle position.

\section{Managerial Implications, Limits, and Further Research}

This cross-cultural research provides the first investigation of the effects of placement from a demand-side perspective in four different countries: two Western Europeans, one Eastern European and a South Mediterranean one. This study presents theoretical and managerial implications.

On the theoretical level, this research proposes to consider dimensions of the placement, not yet studied in the literature: the product placement creative techniques. Which consist of the combination of three categories: audio-visual context, integration and prominence.

On a practical level, the study showed interesting results. The main ones are presented in the table 9, which highlight some key differences in attitudes toward communication in general and product placement in particular. Furthermore, these results confirm conclusions from previous research, especially with regard to two key elements. First, placing products and brands in entertainment media offers an excellent communication tool internationally, often more effective than traditional television advertisement. Second, placement effectiveness at the international level depends on the attitudes of the target markets. Globally, some real and important differences exist among cultures with regard to the appreciation of advertisements, product placements in general, and product placement creative techniques in particular. Consequently, the assumption that a movie travels throughout the world and that a brand featured in that movie will have the same impact in the various countries is, at the very least, questionable. Not only do consumers' acceptances of the techniques differ, but the placement implementation also depends on different cultures.

Table 9. Main results of the study

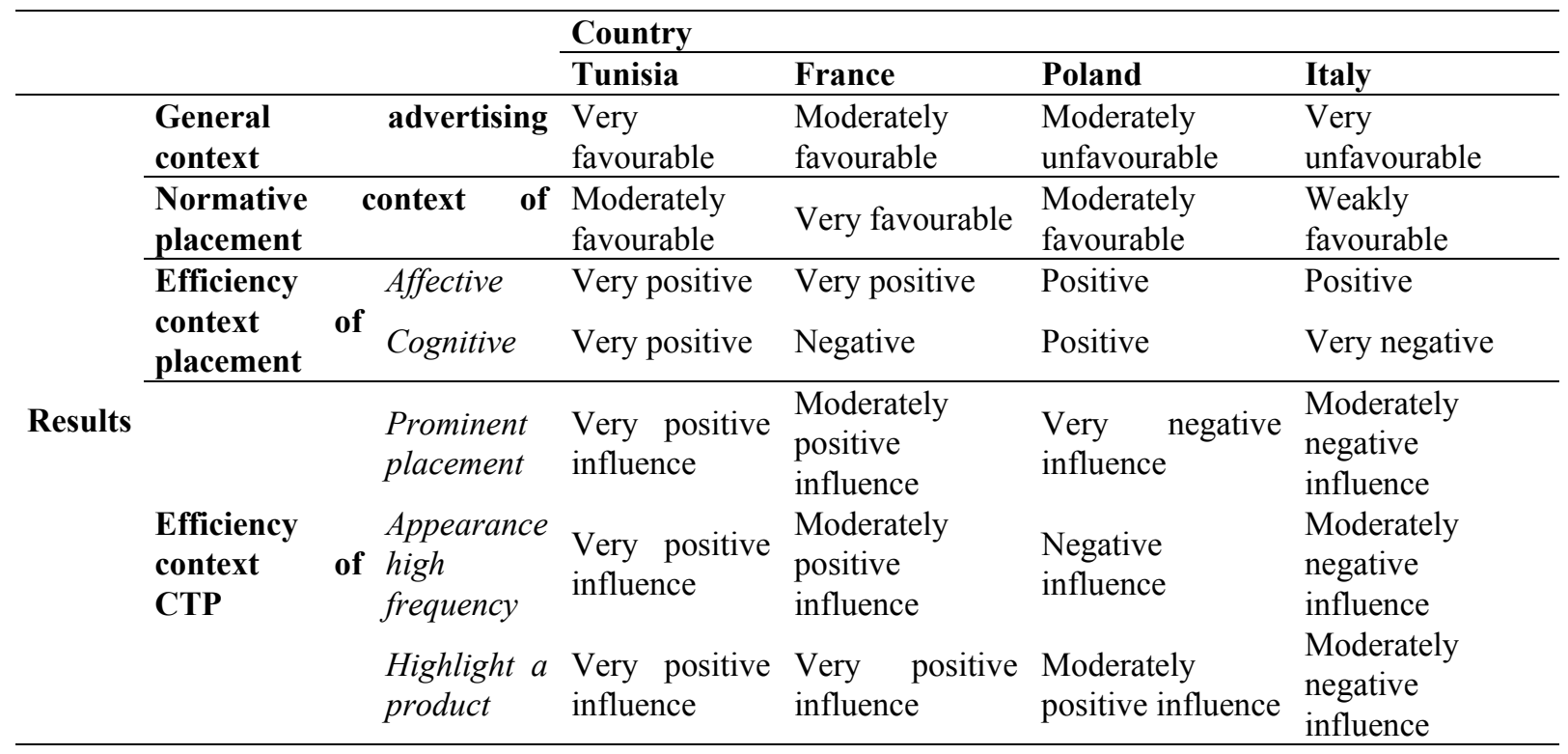

This research also presents some limitations. First, the use of a student sample, even if these consumers are important and justified for this research, does not allow a generalization to other audience segments. Second, this intercultural study relies on the declared attitudes of the respondents, the intention behind the placement persuasive technique is explicit, and participants are conscious of this intent. Such an evaluation cannot identify unconscious attitudes and behaviours, especially the effect of the emotions prompted by the media. For these reasons, complementary studies that focus on movies intended for the international public, for example, will enrich the results herein. Furthermore, future research should also include other Eastern European countries, in order to investigate if they can be considered similar to the Polish sample or if cross-cultural differences exist despite similarities due to the heritage of historical events and to geographic proximity. Finally, attitudes towards brand placement in the four countries should be analyzed again in the following years and compared with current 
results, with the purpose to explore if attitudes become more homogeneous with the globalization of the communication system.

\section{References}

Andrews, J. C., Durvasula, S., \& Netemeyer, R. G. (1994). Testing the cross-national applicability of U.S. and Russian advertising belief and attitude measures. Journal of Advertising, 23(1), 71-82.

Babin, L., \& Carder, S. (1996). Viewers' recognition of brand placed within a film. International Journal of Advertising, 15, 140-151.

Balasubramanian, S. K., Karrh, J. A., \& Patwardhan, H. (2006). Audience response to product placements. Journal of Advertising, 35(3), 115-141. http://dx.doi.org/10.2753/JOA0091-3367350308

Banerjee, S. (2009). Marketing communication through brand placement: a strategic roadmap. Journal of Marketing \& Communication, 5(2), 4-22.

Batra, R., \& Ray, M. (1986). Affective responses mediating acceptance of advertising. Journal of Consumer Research, 12, 234-249. http://dx.doi.org/10.1086/209063

Biel, A. (1990). Love the ad. Buy the product? ADMAP, September, 21-25.

Brée, J. (1996). Le placement de produit dans les films: une communication originale. Décisions Marketing, 8(May / August), 65-74.

Cowley, E., \& Barron, C. (2008). When product placement goes wrong: the effects of program liking and placement prominence. Journal of Advertising, 37(1), 89-98. http://dx.doi.org/10.2753/JOA0091-3367370107

D’Astous, A., \& Séguin, N. (1999). Consumer reactions to product placement strategies in television sponsorship. European Journal of Marketing, 33(9-10), 896-910. http://dx.doi.org/10.1108/03090569910285832

Dalli, D. (2005). Il product placement tra realismo cinematografico e comunicazione pubblicitaria. Economia e Management, 9(4).

Delorme, D., Mennicken, C., \& Haleff, H. (2000). A cross-cultural evaluation of consumers' perceptions and evaluation of brand placement in motion pictures. Conference Proceedings, 11(Winter), 27-34. American Marketing Association.

Englis, B. G., Solomon, M. R., \& Olofsson, A. (1993). Consumption imagery in music television: a bi-cultural perspective. Journal of Advertising, 22(4), 21-33.

EU. (2007). Directive 2007/65/EEC, 11 December 2007. Retrieved from http://eurlex.europa.eu/LexUriServ/LexUriServ.do?uri=OJ:L:2007:332:0027:0045:EN:PDF

Falcy, S. (1997). Les processus d'influence publicitaire: un essai de modélisation intégrant implication vis à vis de la publicité, caractéristiques psychologiques et publicitaires. Thesis in management sciences, Ecole Supérieure des Affaires, Grenoble.

Fontaine, I. (2000). Proposition d'un cadre théorique pour l'étude de l'efficacité de la technique de placement de produits dans les films. Acts of $16^{\text {ème }}$ congress of the Association Française du Marketing, Montréal, 969-984.

Fontaine, I. (2006). Etude du changement d'attitude pour les marques placées dans les films: persuasion ou effet d'exposition? Recherche et Applications en Marketing, 21(1), 1-18.

Galician, M. L. (2004). Handbook of product placement in the mass media: new strategies in marketing theory, practice, trends, and ethics. Binghamton, NY: Best Business Books.

Gardner, M. (1985). Does attitude toward the ad affect brand attitude under a brand evaluation set? Journal of Marketing Research, 22, 192-198. http://dx.doi.org/10.2307/3151364

Gould, S., Gupta, P., \& Grabner-Kräuter, S. (2000). Product placements in movies: a cross cultural analysis of Austrian, French and American consumers' attitudes toward this emerging, international promotional medium. Journal of Advertising, 29(4), 41-58.

Guido, G., Peluso, A., Tedeschi, P., Nicole, C., Lauretti, C., \& Caciula, A. (2010). Acceptance of product placement in Italy: effects of personality and product / consumer interactions. International Journal of Marketing Studies, 2(2), 34-46.

Guillaume, E. (2002). Goldmaker. Editions Fayard.

Gulyas, A. (2003). Print media in post-communist East Central Europe. European Journal of Communication, 18(1), 81-106. http://dx.doi.org/10.1177/0267323103018001227 
Gupta, P., \& Gould, S. (1997). Consumer's perceptions of the ethics and acceptability of product placements in movies: product category and individual differences. Journal of Current Issues and Research in Advertising, 14(Spring), 37-50. http://dx.doi.org/10.1080/10641734.1997.10505056

Gupta, P., \& Lord, K. (1998). Product placement in movies: the effect of prominence and mode on audience recall. Journal of Current Issues and Research in Advertising, 20(1), 47-59. http://dx.doi.org/10.1080/10641734.1998.10505076

Gupta, P., Balasubramanian, S., \& Klassen, M. L. (2000). Viewers' evaluations of product placements in movies: public policy issues and managerial implications. Journal of Current Issues and Research in Advertising, 22(2), 41-52. http://dx.doi.org/10.1080/10641734.2000.10505107

Heyder, H., Musiol, K., \& Peters, K. (1992). Attitudes toward advertising in certain key east and west European countries. Marketing and Research Today, March, 58-67.

Holbrook, M., \& Batra, R. (1987). Assessing the role of emotions as mediators of consumer responses to advertising. Journal of Consumer Research, 14, 404-420.

Karrh, J., Frith, K. T., \& Calisson, C. (2001). Audience attitudes towards brand (product) placement: Singapore and United States. International Journal of Advertising, 20(1), 3-24.

Karrh, J., McKee, K., \& Pardun, C. (2003). Practitioners' evolving views on product placement effectiveness. Journal of Advertising Research, June, 138-149.

Khalbous, S. (2003). Communication marketing et cultures: une application au cas des consommateurs tunisiens. Acts of $19^{\text {ème }}$ congress of the Association Française du Marketing, Tunis, 886-908.

Khalbous, S., \& Maazoul, M. (2005). Placement de produit, media et publicité: quelles interactions? Conceptualisation et étude empirique en Tunisie. Acts of $21^{\text {eme }}$ congress of the Association Française $d u$ Marketing, Nancy.

Kouli, J., \& Saad, G. (2000). Le placement des produits dans les films : une comparaison interculturelle France/ Etats-Unis. Acts of $16^{\text {ème }}$ congress of the Association Française du Marketing, Montréal, 985-1001.

Lee, T., Sung, Y., \& Gregorio, F. (2011). Cross-cultural challenges in product placement. Marketing Intelligence and Planning, 29(4), 366-384. http://dx.doi.org/10.1108/02634501111138545

Lehu, J. M., \& Bressoud, E. (2008). Effectiveness of brand placement: new insights about viewers. Journal of Business Research, 61, 1083-1090. http://dx.doi.org/10.1016/j.jbusres.2007.09.015

MacKenzie, S. B., \& Lutz, R. J. (1989). An empirical examination of the structural antecedents of attitude toward the ad in advertising pretesting context. Journal of Marketing, 53, 48-65. http://dx.doi.org/10.2307/1251413

Malhotra, N., Décaudin, J. M., \& Bouguerra, A. (2004). Etudes marketing avec SPSS. Paris: Pearson Education.

Marinov, M. A., Marinova, S. T., Manrai, L. A. \& Manrai, A. K. (2001). Marketing implications of communist ideological legacy in culture in the context of Central and Eastern Europe. Journal of Euromarketing, 11(1), 7-35. http://dx.doi.org/10.1300/J037v11n01_02

McKechnie, S., \& Zhou, J. (2003). Product placement in movies: a comparison of Chinese and American consumers' attitudes. International Journal of Advertising, 22(3), 349-374.

McQuail, D. (2002). The media and lifestyle. European Journal of Communication, 17(4), 427-428. http://dx.doi.org/10.1177/02673231020170040101

Morton, C., \& Friedman, M. (2002). I saw it in the movies: exploring the link between product placement belief and reported usage behaviour. Journal of Current Issues and Research in Advertising, 24(2), 33-40. http://dx.doi.org/10.1080/10641734.2002.10505133

Nebenzahl, I., \& Secunda, E. (1993). Consumers' attitudes toward product placement in movies. International Journal of Advertising, 12(1), 159-175.

Orth, U. R., Koenig, H. F., \& Firbasova, Z. (2007). Cross national differences in consumer response to the framing of advertising messages: an exploratory comparison from Central Europe. European Journal of Marketing, 41(3/4), 327-348. http://dx.doi.org/10.1108/03090560710728363

Petrovici, D., \& Marinov, M. (2007). Determinants and antecedents of general attitudes toward advertising: a study of two EU accession countries. European Journal of Marketing, 41(3/4), 307-326. http://dx.doi.org/10.1108/03090560710728354 
Poncin, I. (2007). Le placement de produits : un nouvel outil de persuasion de l'enfant consommateur. Revue Française du Marketing, 214(4/5), 43-58.

Poncin, I., \& Pieters, R. (2002). Effets d'assimilation et de contraste dans les réactions affectives induites par les annonces télévisées : l'impact de la similarité thématique et du mode de traitement. Acts of $18^{\text {ème }}$ congress of the Association Française du Marketing, Lille, 331-350.

Rothenberg, R. (1991). Critics seek F.T.C. action on products as movie stars. The New York Times, 31(May).

Rubbo, N., \& Berneman, C. (2004). La pratique du placement de produit dans le cinéma américain : Une analyse de contenu de films entre 1985 et 2001. Acts of the $9^{\text {emes }}$ Journées de Recherche en Marketing de Bourgogne, $36-55$.

Russell, C. A. (1998). Toward a framework of product placement: theoretical propositions. Advances in Consumer Research, 25, 357-362.

Russell, C. A. (2002). Investigating the effectiveness of product placement in television shows: the role modality and plot connection congruence on brand memory and attitude. Journal of Consumer Research, 29(December), 306-318. http://dx.doi.org/10.1086/344432

Smit, E., van Reijmersdal, E., \& Neijens, P. (2009). Today's practice of brand placement and the industry behind it. International Journal of Advertising, 28(5), 761-782. http://dx.doi.org/10.2501/S0265048709200898

Tiwsakul, R., Hackley, C., \& Szmigin, I. (2005). Explicit, non-integrated product placement in British television programmes. International Journal of Advertising, 24(1), 95-111.

Turner, K. J. (2004). Insinuating the product into the message: an historical context for product placement. Journal of Promotion Management, 10(1/2), 9-14. http://dx.doi.org/10.1300/J057v10n01_02

Usunier, J. C., \& Lee, J. A. (2005). Marketing across Cultures. New York-London, Financial Times/Prentice Hall.

Walker, D., \& Dubitsky, T. (1994). Why liking matters. Journal of Advertising Research, May/June, 9-17.

Yang, M., \& Roskos-Ewoldsen, D. R. (2007). The effectiveness of brand placement in the movies: levels of placement, explicit and implicit memory and brand choice behavior. Journal of Communication, 57, 469-489. http://dx.doi.org/10.1111/j.1460-2466.2007.00353.x

Appendix 1. Measurements of the variables of the study

\begin{tabular}{|c|c|c|}
\hline Variables & Scales /Items / Measure & \\
\hline \multirow{3}{*}{$\begin{array}{l}\text { General attitudes } \\
\text { advertisement }\end{array}$} & $\begin{array}{l}\text { About the existence of advertising in various media } \\
\text { (television, cinema, radio, press and poster), you are: }\end{array}$ & $\begin{array}{l}\text { Favourable } \\
\text { unfavourable } \\
\text { (5 points) }\end{array}$ \\
\hline & $\begin{array}{l}\text { What can you say about your personal feelings } \\
\text { toward advertising: }\end{array}$ & $\begin{array}{l}\text { I like / I dislike } \\
\text { ( } 5 \text { points) }\end{array}$ \\
\hline & In general, you tend to look at advertising: & $\begin{array}{l}\text { Often/seldom } \\
(5 \text { points })\end{array}$ \\
\hline $\begin{array}{l}\text { Normative attitude } \\
\text { placement }\end{array}$ & $\begin{array}{l}\text { For you, the presence of brands in programs is a } \\
\text { technique that must be: }\end{array}$ & $\begin{array}{l}\text { Free / used with } \\
\text { caution / prohibited }\end{array}$ \\
\hline \multirow{10}{*}{ General attitude toward placement } & That I do not pay attention & \multirow{10}{*}{$\begin{array}{l}\text { Agree / disagree } \\
(5 \text { points })\end{array}$} \\
\hline & Nice & \\
\hline & Misleads the consumer & \\
\hline & More attractive than traditional advertising & \\
\hline & Changes people's behavior towards a brand & \\
\hline & $\begin{array}{l}\text { Dangerous because it affects the consumer } \\
\text { unconsciously }\end{array}$ & \\
\hline & More credible than traditional advertising & \\
\hline & Encourage purchase & \\
\hline & More boring than traditional advertising & \\
\hline & Allows consumer to better understand product usage & \\
\hline
\end{tabular}


Appendix 2. Measurement of the attitudes toward creative techniques

\begin{tabular}{|c|c|c|c|}
\hline Variable & $\begin{array}{l}\text { Creative } \\
\text { Dimensions }\end{array}$ & Scales / Items / Measure & \\
\hline \multirow{9}{*}{$\begin{array}{l}\text { Attitudes toward } \\
\text { creative } \\
\text { techniques }\end{array}$} & Visual / prominent & $\begin{array}{l}\text { High frequency of occurrence of the brand in } \\
\text { the movie or the soap opera }\end{array}$ & \multirow{9}{*}{$\begin{array}{l}\text { Positive influence } \\
\text { négative influence } \\
\text { ( } 5 \text { points) }\end{array}$} \\
\hline & $\begin{array}{l}\text { Audio-visual } \\
\text { central }\end{array}$ & $\begin{array}{l}\text { Product associated to the hero of the film or } \\
\text { soap opera }\end{array}$ & \\
\hline & $\begin{array}{l}\text { Audio-visual } \\
\text { subtle }\end{array}$ & $\begin{array}{l}\text { Discreet presence of the brand in the movie or } \\
\text { the soap opera }\end{array}$ & \\
\hline & Verbal / prominent & $\begin{array}{l}\text { Attractive manner with which the actor cites } \\
\text { the brand name (tone of the voice, way to } \\
\text { speak...) }\end{array}$ & \\
\hline & Visual / central & $\begin{array}{l}\text { Importance of the product in the movie or the } \\
\text { soap opera (the film's story, the } \\
\text { atmosphere...) }\end{array}$ & \\
\hline & Visual / peripheral & Product in foreground & \\
\hline & $\begin{array}{l}\text { Audio-visual / } \\
\text { peripheral }\end{array}$ & $\begin{array}{l}\text { Product associated to a secondary character in } \\
\text { the movie or the soap opera }\end{array}$ & \\
\hline & $\begin{array}{l}\text { Audio-visual } \\
\text { prominent }\end{array}$ & $\begin{array}{l}\text { Draw attention to the product by the color, } \\
\text { size, effect of movement, sound... }\end{array}$ & \\
\hline & Verbal / prominent & $\begin{array}{l}\text { High frequency of verbal citation of the brand } \\
\text { name }\end{array}$ & \\
\hline
\end{tabular}

